\title{
Misleading minds and playing with senses in the works of H.G. Wells
}

\section{Veronika Briatková}

Veronika Briatková is a PhD student at Palacký University in Olomouc, Czech Republic. Her research focuses on the portrayal of mad scientists in the literature of $\mathrm{H}$. G. Wells, using cognitive approaches to literature, mainly cognitive narratology. She is also interested in horror studies in literature and film from cognitive and evolutionary perspectives.

\begin{abstract}
Wings flapping in the dark, a scientist who is able to be present in two places at once as a result of an accident in the laboratory, and unknown creatures hiding in the shadows. This paper focuses on those works of English writer H.G. Wells (1866-1946) which create mystery by playing with human perception and the human senses. In these stories, the mysteries might have a real cause, or they might be a result of confusion. Either way, it certainly makes the characters question the reliability of their minds. They shudder with fear, and sometimes they are on the verge of losing their sanity. These phenomena are examined from the perspective of cognitive approaches. The analysis focuses on mental processing and how it influences the mental stability of the characters in question. One of the questions asked is what kinds of responses are elicited by these mysteries involving potentially misled senses.
\end{abstract}

"It seemed to me to hit out with its claws pretty freely. That is about as much as I know about the beast. Our conversation was intimate, so to speak, and yet not confidential"

(Wells, 1957, p. 219).

The influence of fear on the human mind is a significant issue portrayed in the literature of horror and terror. The short stories The Moth (1895) and The Red Room (1896) written by H.G. Wells explore the developmental stages of fear by placing the main characters in darkness together with an unknown creature which leads them to doubt their own beliefs and even their own sanity. These particular short stories were chosen because the creatures are creations of the human mind and initially do not seem to cause any physical harm. Cognitive narratology and theories related to how minds process information from their surroundings will be used to uncover how fear can develop from a relatively harmless emotion to a potentially damaging one.

Losing the ability to see properly and how it affects the human mind made its way into several of H.G. Wells' stories, for example, The Remarkable Case of D avidson's Eyes (1895). 
Davidson loses the ability to see the environment in which his body is present, but he gains the ability to see an unknown island as if his body were present there, too. This change is a result of an accident in his laboratory. He is scared and thinks he has died but when his normal vision slowly starts to return and the unknown island starts to disappear he is eager to see as much of the unknown place as possible. Davidson takes advantage of the sudden change that has impacted his vision and wants to understand how it happened in order to replicate the accident and investigate the possibilities of such an ability. It is not always that an impaired and changed ability of vision prompts scientific curiosity and sometimes it might be more difficult to dispose of fear that comes with such change.

Fear can develop into more extreme emotions: the emotion of horror and the emotion of terror. The distinction between horror and terror lies in the origin of the object that causes the character to feel afraid. This object can be of supernatural origin, sci-fi origin or can come from the natural world on Earth. The object of supernatural or sci-fi origin is a monstrous creature such as a vampire, a zombie, an alien or any creature that is perceived as unnatural (Carroll, 1990, p. 15). An unnatural monster is a mixture of two categories, for example, dead and alive, or wolf and human (Carroll, 1990, p. 43-45). In certain cases, objects that seem natural might become horror monsters through the process of magnification (enlargement) or massification (massive numbers of the same object) (Carroll, 1990, p. 47-52). Sometimes, the object is not horrific in itself but is associated with something impure or revolting (Carroll, 1990, p. 52).

The objects (from now on referred to as creatures) featured in the selected short stories are a moth and a ghost. The origin of such creatures in itself does not explain why the emotions they elicit in characters and audiences are horror or terror, because ghosts can feature in fairytales, too. Instead, it is explained by their connection with impure and evil things. What happens after the creature is established as scary and the characters are afraid of it is also intriguing and worth analysing. This paper focuses on the analysis of fictional worlds, namely the development of characters' minds when they are forced to deal with fear and creatures that threaten their lives and mental health.

The quotation at the beginning is a testimonial of the main character of "In the Avu Observatory" (1894). The main character, Woodhouse, describes his interaction with the beast that attacked him, in the form of a conversation. Woodhouse is forced to face an animal which attacks him at night and which he is unable to see. Woodhouse fears the animal because it physically attacks him and almost kills him which makes the story unfit for the purposes of fear analysis in this paper. Nevertheless, the observation he makes is crucial. Characters always interact with their environment, and although none of the creatures in question is human, the 
interaction has the same features as it does between humans in terms of cognitive exchange. Humans have an ability to assign mental states to other human beings and this ability is an exchange of information as regards a conversation partner (Gopnik, 1999, p. 838-841). This ability allows the reading of other people's minds and it happens constantly and unconsciously. Naturally, this is not a true act of mind-reading in terms of having psychic powers, and therefore the mental state that is assigned to another person might not always accurately reflect their true state of mind (Zunshine, 2006, p. 13). Multiple factors can have an influence on mind-reading, including what Zunshine refers to as "noise", for example, cultural, gender and social contexts (2006, p. 39). These discourses shape how we process information and are subject to change overtime. This paper, however, does not focus on the interpretation of fear as a commentary on any of those discourses. The focus is on the process that starts at the moment fear enters the human mind. Rabinowitz describes the following factors that influence the accuracy of mindreading: emotional valence, reciprocity, multiplicity, depth, angle, occlusion (sincerity and perspicacity), mode (fictionality) and consistency (2015, p. 89-92).

Depth is connected to "embedded intentionality" as discussed by Zunshine (2006, p. 27-36). Characters can report the situation by layering information accessed by the act of mind-reading. For example: Peter suspects Mary believes that Jack does not like Anna. The first level and first layer of mind-reading is the information that Jack does not like Anna. The second level of mindreading is the information that Mary believes that Jack does not like Anna. This second level already contains another different level of mind-reading. The third level is the information that Peter suspects that Mary believes that Jack does not like Anna. This sentence includes three different levels of mind reading embedded in each other. Imbedded intentionality, however, is not used to such an extent in these stories that it would seem to influence characters' mindreading ability and attention will be dedicated to other factors. The same applies to the mode, which is concerned with mind-reading exchanges that could have been or would have been and are not happening at the actual time the conversation takes place. Angle and multiplicity is excluded from the analysis because it becomes more relevant when an exchange is happening between more than two objects, unlike here, where the focus is on the exchange between two objects, the main character and the creature.

Each act of mind-reading is accompanied by an act of mind-writing (Rabinowitz, 2015, p. 88) and this distinction becomes relevant for the analysis of creatures and their influence on the main characters, the mind-readers. Mind-reading would be impossible without the information that is put out by the mind-writer to read. 
The conditions in the ideal situation should be as follows: no extreme emotion; all participants exchange roles of mind-readers and mind-writers to the same degree (reciprocity); they do not conceal any information from each other (occlusion) and all mind-writers and mindreaders perform their activities with equal consistency at all times (Rabinowitz, 2015, p. 91). The instability of emotional valence, occlusion, consistency and reciprocity increases the impact of fear on the human mind.

Every interaction is influenced by characters' emotions and this is referred to as emotional valence. This factor is crucial in analysing fear because a high degree of emotional valence results in clouded judgment, especially if the character and the object that causes the fear are isolated from the rest of the world.

The Moth tells the story of an entomologist called Hapley, who gradually loses his sanity because he starts seeing a moth that does not exist in the real world. The moth is a creature of his own mind, refuses to leave him and bothers him day and night. Hapley sees the moth for the first time one evening in a room in a house in a village where he retreats after the death of Pawkins, who was also an entomologist and with whom he had an ongoing dispute. Happley feels there is a gap in his life after Pawkins's death because he built his career around his feud with Pawkins. Hapley loses something that kept him going and without a purpose in life he starts getting depressed, and a doctor advises him to take a rest. When he sees the moth, his thoughts go immediately back to Pawkins. The story concludes with Hapley ending up in an asylum and referring to the moth as "the ghost of Pawkins" (Wells, 1957, p. 312).

While Hapley hallucinates, the protagonist of "The Red Room" is temporarily scared by an experience with a supernatural being which is not created by a disease of the brain but by fear alone. In the end he is able to understand his own experience and he does not go insane. The ghost that he is supposed to encounter in the red room of an abandoned house is supposedly a ghost of one or more people that died in the house. This story has a setting and beginning that mostly resemble those of gothic stories: an abandoned house haunted by a ghost and caretakers who do not dare to enter a room and who seem to be ghosts themselves.

Darkness is ever-present in both stories and so is a creature, "a monster" (Wells, 1957, p. 312) that is threatening the main characters. Darkness can take many forms: an absence of light or an inability to see things as they really are due to an obstruction. The protagonists cannot talk to the creatures, but they can partially observe them and their actions. The mind-readers cannot perform mind-reading properly because they cannot see the creatures in their entirety. They try to solve the problem by relighting candles or catching the moth. Darkness acts as an 
occlusion as it creates a barrier and characters cannot extract enough information. It is the beginning of a cycle in which fear takes over characters' minds and also their sanity.

The character expresses this sentiment after he lights seventeen candles in the red room: "The room was now quite brightly illuminated. There was something very cheery and reassuring in these little streaming flames, and snuffing them gave me an occupation, and afforded a reassuring sense of the passage of time" (ibid., p. 453). The character needs the reassurance because gradually he confesses he is "in a state of considerable nervous tension" (ibid., p. 452) although his mind is still "perfectly clear" (ibid.). Everything starts to change when the first candle goes out and he turns to face the corner and sees "that the darkness was there" (ibid., p. 453). The candles then start to go out one after another at an increasing pace, making the character feel "almost frantic with the horror of the coming darkness, and my selfpossession deserted me" (ibid., p. 454). The faster he moves through fear, the darker it gets. It is a downward spiral because fear increases darkness, and darkness increases occlusion which increases fear and so on. The accuracy of Hapley's mind-reading is influenced largely by emotional valence and occlusion due to darkness.

The ghost from the red room is an interesting creature because he is a creation of the human mind. The ghost never appears but the character sees him manifested in the candles that go out. The question is who or what exactly is the mind-writer that Hapley is mind-reading. The candles going out could be interpreted as an act of mind-writing from the ghost; however, the ghost never appears. The main character is eventually so scared he loses his sense of direction and hits himself on the corner of the bed as he falls down. The caretakers find him and when he wakes up he describes what is haunting the red room:

"The worst of all the things that haunt poor mortal man," said I; "and that is, in all its nakedness-Fear! Fear that will not have light nor sound, that will not bear with reason, that deafens and darkens and overwhelms. It followed me through the corridor, it fought against me in the room" (ibid., p. 456).

At this moment, one of the caretakers concludes the story, making the connection between darkness and fear, further emphasizing "a power of darkness" (ibid., p. 456). The need to relight the candles reflects the mind's need to decrease occlusion and the need to uncover the identity of the second participant. The character assigns the mind-writing to a mind-writer that does not exist, the ghost. He is constantly talking aloud as if someone were in the room with him. The 
unsuccessful mind-reading attempt results in greater confusion which further leads to the loss of orientation and eventually injury.

A similar need to uncover the identity of the second participant is apparent in "The Moth." Hapley has some trouble spotting the moth at the beginning for more than a brief moment: "After the fashion of its kind, it flew with sudden starts and turns, seeming to vanish here and reappear there" (ibid., p. 307). Hapley does not have enough information to mind-read the month. He wants to identify the moth because he supposes it is a new species and "nothing would have maddened Pawkins more" (ibid., p. 307). At this moment, Hapley is unaware that the moth is a creation of his own mind. Hapley's mind was craving the energy and attention that he received while Pawkins was still alive, and this is the reason the moth was created. Hapley wants to catch the moth but not only is the moth fast, it is also flying in a darkened room because he has accidentally damaged the lamp. Eventually, Hapley is able to see the moth in the daylight but his eyes seem to deceive him: "Instead of a butterfly looking like a stone, here is a stone looking like a butterfly!" (ibid., p. 309). He does not realize until his conversation with the vicar that he is the only one who sees the moth. Hapley is aware of his situation; he knows stress might have caused such a hallucination, but he is alarmed he can also hear and feel the moth. After this realization he is finally able to see the moth clearly: "He saw the hairy body and the short feathery antennae, the jointed legs even a place where the down was rubbed from the wing" (ibid., p. 310). The image of moth is no longer unclear and therefore occlusion by darkness no longer plays a role. Hapley is able to mind-read the whole situation and he knows he has to say the moth does not exist in order to avoid being placed in an asylum. At this moment, the moth represents the fear of losing one's sanity. The moth becomes the darkness, the barrier which intercepts his ability to mind-read the world around him accurately. He claims that the moth does not exist to avoid being institutionalized, but his behaviour reveals he still sees the moth. The moth never leaves Hapley, and the more he tries to catch it the madder he appears to people around him. Eventually, his mind is preoccupied with the moth to such an extent that Hapley sees no other purpose in life than to catch the moth and study it.

The creatures are creations of the mind in both cases and therefore they cannot be active mind-writers. Reciprocity, the degree to which mind-readers and mind-writers exchange roles must be approached from a different perspective. Actively, there is no exchange and therefore no reciprocity because there does not exist any other character that would enter the exchange. Yet, the ghost and the moth are mind-writers in a sense that they reflect inner fears and insecurities. Furthermore, it is important to make a distinction between a creature that is a result of mental disease and which will never leave and between a creature that will eventually cease 
to exist. In the first case, the protagonist is able to think clearly when he is removed from the influence of darkness in the red room. Hapley's mind will never be able to remove itself from the moth which becomes the only focus of mind-reading for the rest of his life.

Objects of fear vary not only in the manner they are created - that is through fusion, fission, massification, enlargement and horrific metonymy - but also in how they influence the mind. After the creatures are established as the source of fear they interfere with processes that help the character understand their own situation. The role of three factors has been considered so far: occlusion, reciprocity and emotional valence. The occlusion in the stories took the form of darkness, which was expected as darkness is traditionally connected with things unknown and impure and is present in almost all stories of terror and horror. The occlusion however had unexpected aftereffects. It acted as a catalyst that started the cycle by which the power of emotional valence to influence mind-reading became greater and greater. The accuracy of mind-reading, the fourth factor, also suffers as a result. The protagonists focus all their attention to try and mind-read the creature as accurately as possible but not within the context of the surrounding world. The man in the red room does not consider other factors that might cause candles to go out, for example, the draft created by his own movement. He also does not think about the effect of fear on his perception until he wakes up in the daylight. Hapley pretends he is sane but eventually his disease, which is caused by the fear of insignificance, forces him to focus only on the moth.

Both characters are fuelled by knowledge and curiosity, and fear takes the form of creatures that are born in their minds. This paper approached the question of what happens after fear enters the human mind from the angle of cognitive narratology. Looking closely at factors that interfere with mind-reading revealed some differences and similarities in the developmental stages of fear, mainly the cycle of escalation which leads to mental and physical harm without any cause from outside.

\section{Works cited:}

Carroll, N. 1990. The Philosophy of Horror or Paradoxes of the Heart. London: Routledge. Gopnik, A. 1999. Theory of Mind. In Wilson, R. A. and Frank C. K. (eds.). The MIT Encyclopedia of the Cognitive Sciences. Cambridge: MIT Press, p. 838-841.

Rabinowitz, P. J. 2015. Toward a Narratology of Cognitive Flavour. In Zunshine, L. (ed). The Oxford Handbook of Cognitive Literary Studies. New York: Oxford University Press, p. 85-103. 
Wells, H.G. 1957. The Moth. In: The Short Stories of H.G. Wells. London: Ernest Benn, p. 302-312. Wells, H.G. 1957. In the Avu Observatory. In: The Short Stories of H.G. Wells. London: Ernest Benn, p. 212-219.

Wells, H.G. 1957. The Remarkable Case of Davidson's Eyes. In: The Short Stories of H.G. Wells. London: Ernest Benn, p. 273-283.

Wells, H.G. 1957. The Red Room. In: The Short Stories of H.G. Wells. London: Ernest Benn, p. 447456.

Zunshine, L. 2006. Why We Read Fiction: Theory of Mind and the Novel. Columbus: The Ohio State University Press.

Veronika Briatková

A.Štefanku $3 / 29$

Žiar nad H ronom

96501

Slovenská Republika

briatkova.veronika@gmail.com

\section{Acknowledgement}

This contribution was made possible with the support of the Ministry of Education, Youth and Sports of the Czech Republic, grant no. IGA_FF_2015_IGA_FF_2015_041 (Angloamerická lingvistika, literární věda a translatologie v mezinárodním kontextu). 